\title{
Status of Basic Facilities of Primary Schools: A Case Study of Krishnagar Municipal Area in Nadia District, West Bengal, India
}

\author{
Koushik Barick \\ Guest Lecturer, Dukhulal Nibaran Chandra College, Aurangabad, Murshidabad (W.B) \\ Ex-student, Kalyani University, Nadia (West Bengal)
}

\begin{abstract}
The Krishnagar Municipality is situated in a densely urban area of Nadia District in West Bengal. Primary Education is a base of education in a society. Basic Facility of Primary School is required for a good education (i.e.school building, condition of class room, sanitary system, toilet facility, drinking water facility, play ground etc.) The Student Teacher ratio indicates sustainable teaching in a School. The aim of present work to analysis the condition of basic facility of primary school. The major source of data is Primary Council of Krishnagar in Nadia, Krishnagar municipality Nadia, Publication report and articles. The collected data organized in a master table and represented through tables and relevant mapping and digitized cartographic techniques. The result shows Basic facilities of Primary schools have below standard level, Primary education program and schemes are not properly implies. Maximum number of schools have not maintain good student teacher ratio i.e. 40:1. Therefore increase the basic facility of primary school and also use government initiative i.e. SSA, Midday meal grant for improving lower status of primary school and create cluster format schools. Teaching learning process will develop and use attracting teaching aids, as well as holistic planning urgently needs to occurrence this problem.
\end{abstract}

Keywords: Primary School, Basic Facility, Student Teacher ratio, Krishnagar Municipality

\section{Introduction}

Education is a vital process of the development, which considered one of the main pillars of a society Education is the foundation of all types of developments in the world. It is an established fact that in the world only those nations have made progress and development which have a sound education system Education develops individuals. It creates awareness among the people about life and its challenges in the world. It fills empty minds with ideas and creativity. Thus educationally sound nations play leadership role in the world since its independence the primary system of education could not make progress due to many factors such as parochial feudal and sate politicians, corrupt bureaucracy, authoritarian regimes, fragile civil society and weak democracy. The system of primary education is deliberately neglected in the country. Instead of developing the nation on the basis of free and quality education, the system was hijacked by so-called monsters of democracy and development.

\section{The Study Area}

Krishnagar is a municipality and the administrative headquarters of Nadia district in West Bengal. The Krishnagar municipality was established in 1864 . The area of the municipality is around $16 \mathrm{sq}$. $\mathrm{Km}$. and is divided into 24 wards. Krishnagar is located at $23^{\circ} 23^{\prime} \mathrm{N}$ to $23^{\circ} 26^{\prime} \mathrm{N}$ and $88^{\circ} 28.6^{\prime} \mathrm{E}$ to $88^{\circ} 31.4^{\prime} \mathrm{E}$. It has an average elevation of 14 metres (45 feet) above MSL. Krishnagar is situated beside the Jalangi River and the town is well connected by road and railway junction to different parts of the State. The major agricultural products of the area include rice, jute, and sugarcane. Industrial activities include sugar milling and ceramic manufacturing. Located $100 \mathrm{~km}$ with about general survey land nearby river. North from Kolkata, Krishnagar is on the banks of Jalangi River. It was the residence of raja Krishnachandra, a great patron of art and culture. 78 Primary School are present in this Municipal area.

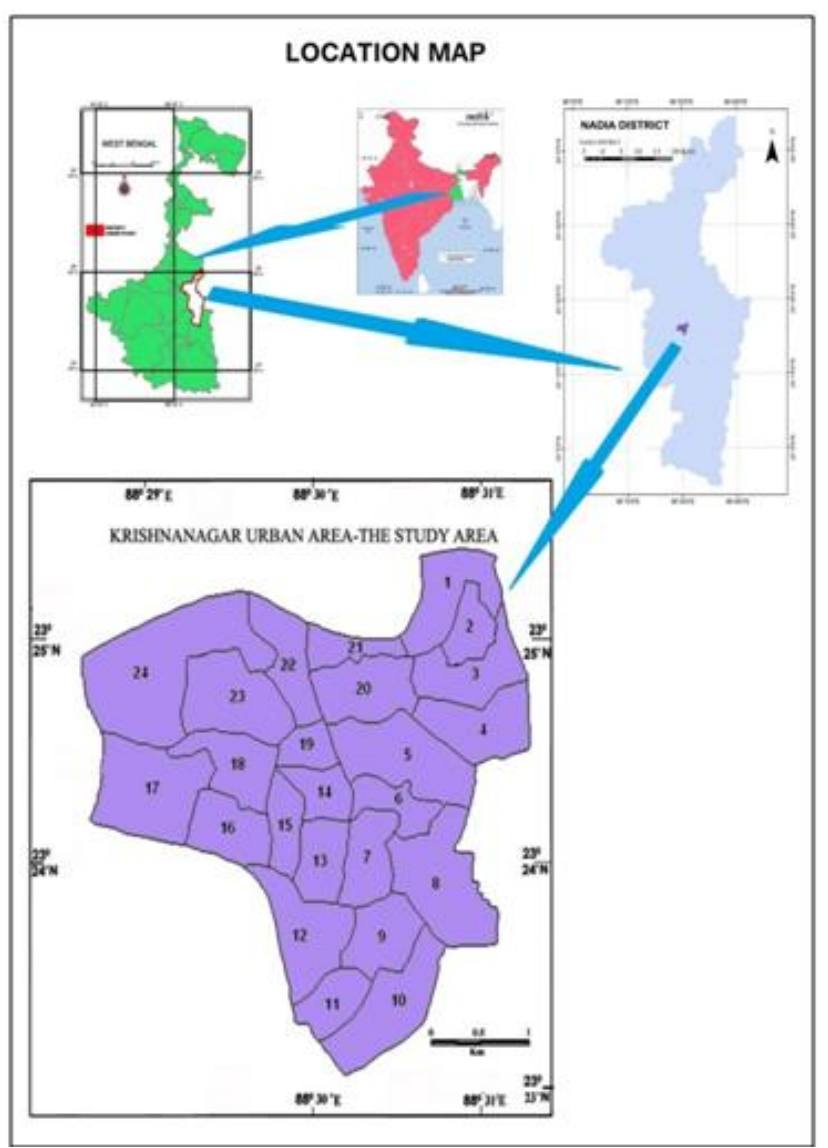




\section{International Journal of Science and Research (IJSR) \\ ISSN (Online): 2319-7064 \\ Index Copernicus Value (2013): 6.14 | Impact Factor (2014): 5.611}

Objectives of the Study

The objects of the study are as follows,

1) To study the status of primary school.

2) To explain the measures taken so far to improve the primary education.

\section{Materials and Methods}

The data, supported documents , maps current information of the survey area are collected from primary Council in Krishnagar,Nadia (Barnaporicaoi Vaban), District Census office, Nadia and Krishnagar Municipal Office. Different location of Primary Schools are identified by GPS survey and prepared Location map of Primary School. Given data are organised in a master table and it's represent relevant cartographic techniques and weighted index Method.

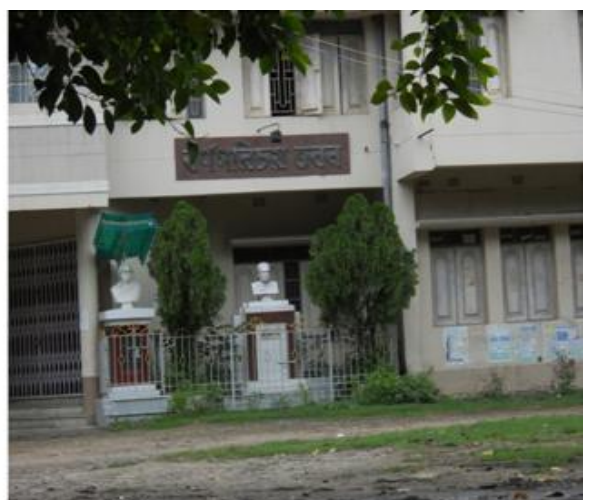

Plate 1: Krishnagar Municipality Estd. 1864 Plate 2: Primary Council, Krishnagar, Nadia (Barnaporichai Vavan)

\section{Results and Discussion}

\section{Population Profile of the Study Area}

It is necessary to examine various aspects of population as it help to understand socio-economic condition of the study area. In the study area have 151760 persons out of which the share of male population is 76605 and female population constitute 75155 .

Table 1: Population Composition in Krishnagar Municipality

\begin{tabular}{|c|c|c|c|}
\hline Ward No. & Male & Female & Total \\
\hline 1 & 4153 & 4001 & 8154 \\
\hline 2 & 3604 & 3470 & 7074 \\
\hline 3 & 4206 & 4081 & 8287 \\
\hline 4 & 4976 & 4024 & 9000 \\
\hline 5 & 5368 & 5304 & 10672 \\
\hline 6 & 3684 & 3382 & 7066 \\
\hline 7 & 2492 & 2482 & 4974 \\
\hline 8 & 2049 & 1943 & 3992 \\
\hline 9 & 2428 & 2424 & 4852 \\
\hline 10 & 4150 & 4033 & 8183 \\
\hline 11 & 2553 & 2495 & 5048 \\
\hline 12 & 3317 & 3428 & 6745 \\
\hline 13 & 2494 & 2483 & 4977 \\
\hline 14 & 2654 & 2712 & 5366 \\
\hline 15 & 2466 & 2579 & 5045 \\
\hline 16 & 2973 & 2987 & 5960 \\
\hline 17 & 3424 & 3205 & 6629 \\
\hline 18 & 2983 & 3137 & 6120 \\
\hline 19 & 2296 & 2418 & 4714 \\
\hline 20 & 1706 & 1794 & 3500 \\
\hline 21 & 2070 & 2128 & 4198 \\
\hline 22 & 2336 & 2328 & 4664 \\
\hline 23 & 2371 & 2429 & 4800 \\
\hline 24 & 5852 & 5888 & 11740 \\
\hline Total & 76605 & 75155 & 151760 \\
\hline
\end{tabular}

Source: Census Data, 2011

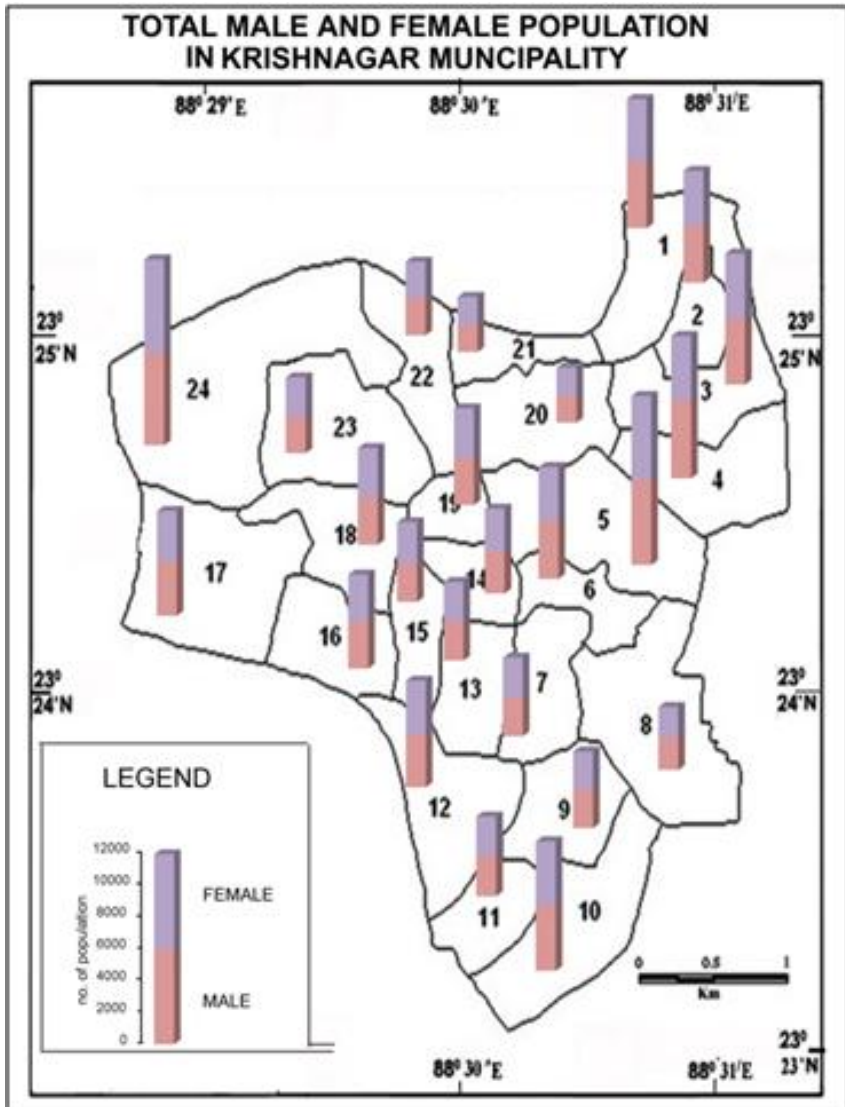

Figure 2: Map Shows Population Composition in Krishnagar Municipality Based on Census 2011

\section{Basic Facility in a Primary School}

For development in a primary School some facilities are available in the school that is called Basic facility. The minimum basic facilities are required for a good education.

\section{Volume 5 Issue 3, March 2016}




\section{International Journal of Science and Research (IJSR) \\ ISSN (Online): 2319-7064 \\ Index Copernicus Value (2013): 6.14 | Impact Factor (2014): 5.611}

The basic facilities are as follows, Structure of school building, number of class rooms, Sanitary system, Toilet facility (separate girls \& boys), drinking water facility, Play ground, number. of Bench, number of Sataranji, Black board, Desk, Maps, Wall Board, Chair, Globe, Pocket board, number table, Chart, Almery, Stock of books in library, Trunk, Paper.

\section{Status of Class Room:}

It is found that total 41 Schools out of 78 Schools i.e. $52.56 \%$ have in bellow four rooms. More over out of 78 schools, 29 Schools (37.17\%) have four to six rooms where as 8 Schools carry on more than Six Rooms. So it is clear minimum classroom not available in 41 Schools (52.56\%). So it is clear $52.56 \%$ Primary School have no sufficient Classroom for a quality education.

Table 2: Status of Class Room

\begin{tabular}{|c|c|c|c|}
\hline No. of Class Room & $<4$ & $4-6$ & $>6$ \\
\hline No. of Primary School & 41 & 29 & 8 \\
\hline \% of Primary School & 52.56 & 37.17 & 10.25 \\
\hline
\end{tabular}

Source: Primary Council, Krishnagar,Nadia.

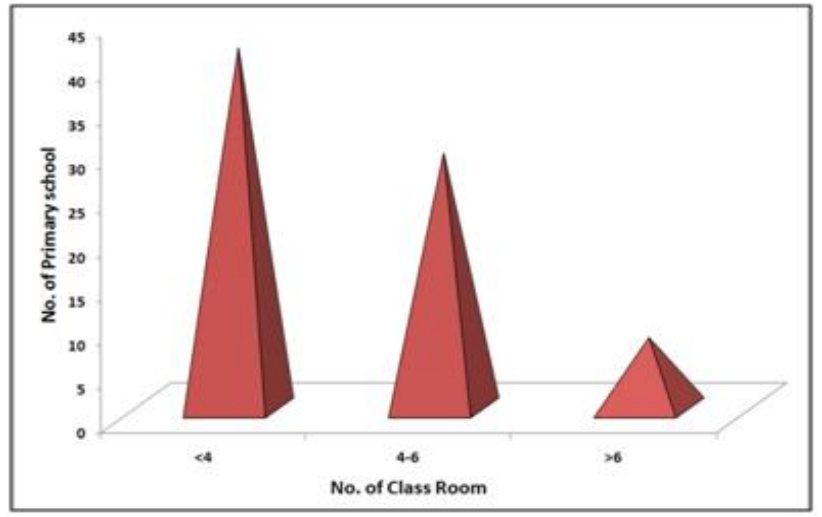

Figure 3: Status of Class Room in Primary school of Krishnagar Municipal area, 2013

\section{Drinking Water Facility}

As is evident from the table, the Drinking Water facility has shown more important in a school. The Percentage of Schools where drinking water facilities are available in the Municipality is $66.66 \%$ but drinking water facilities are not available in 33.33\% Primary School.

Table 3: Drinking water Facility

\begin{tabular}{|c|c|c|}
\hline Drinking Water & Yes & No \\
\hline No. of Primary School & 52 & 26 \\
\hline \% of Primary School & 66.66 & 33.33 \\
\hline
\end{tabular}

Source: Primary Council, Krishnagar, Nadia

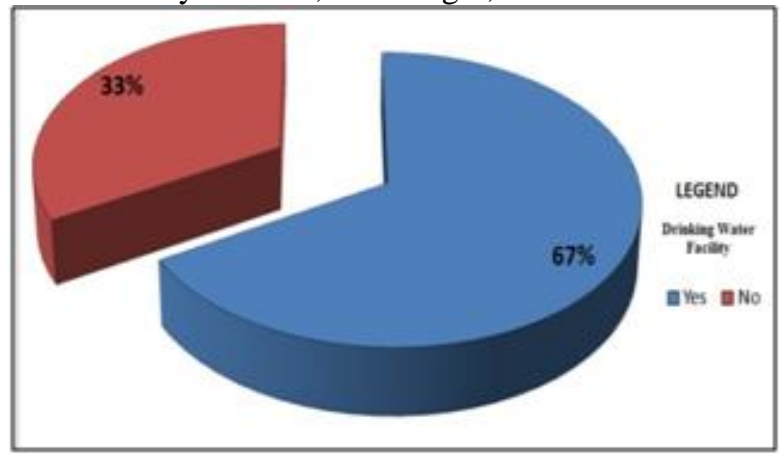

Figure 4: Pie graph Showing drinking water facility of Primary school, Krishnagar

\section{Availability of Bench and Sataranji}

Bench and Sataranji are primary requirements in a school because students are seating on the bench and Sataranji for study. So Bench and Sataranji are basic amenities in a school. It has been found that more than 85\% Primary School of the total Survey School have poor availability of Benches. More than 95\% of the total Survey Primary Schools have small number of Sataranjis i.e. 20. The above discussion reveals that bench and sataranji is an important in the school. The figure shows the available number of bench and Sataranji much poorer.

Table 4: Availability of Bench

\begin{tabular}{|c|c|c|c|}
\hline No. of Benches & $<40$ & $40-60$ & $>60$ \\
\hline No. of Primary School & 67 & 5 & 6 \\
\hline \% of Primary School & 85.89 & 6.41 & 7.69 \\
\hline
\end{tabular}

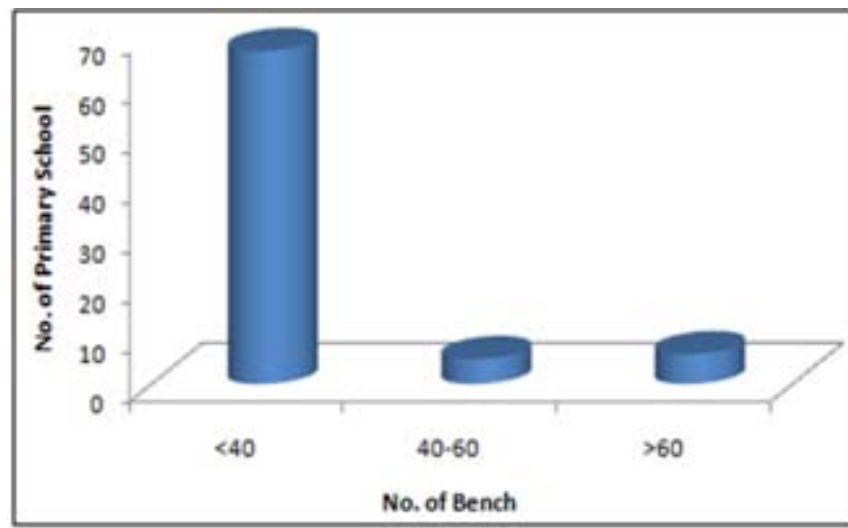

Figure 5: Availability of bench in primary School under Krishnagar municipality

Source: Primary Council, Krishnagar,Nadia.

Table 5: Availability of Sataranji

\begin{tabular}{|c|c|c|c|}
\hline No. of Sataranji & $<20$ & $20-40$ & $>40$ \\
\hline No. of Primary School & 74 & 2 & 2 \\
\hline \% of Primary School & 94.87 & 2.56 & 2.56 \\
\hline
\end{tabular}

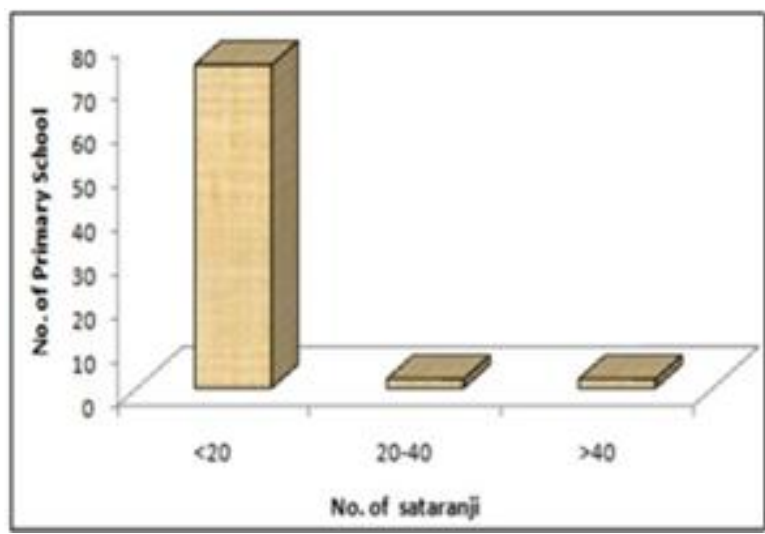

Figure 6: Availability of sataranji in primary School under Krishnagar municipality

Source: Primary Council, Krishnagar,Nadia.

\section{Availability of Black Board}

The Primary school is characterized by below four, Four to Six and Greater than Six number of black boards. Among the primary school during the survey it was observed that maximum primary school belong to below four black boards (57.69\%). The share of four to six and greater than six Black board in the survey school in the locality is more or less 


\section{International Journal of Science and Research (IJSR) \\ ISSN (Online): 2319-7064 \\ Index Copernicus Value (2013): 6.14 | Impact Factor (2014): 5.611}

equal i.e. $37 \%$, while the proportion of greater than Six within the total school is only 5\% (fig.7).

Table 6: level of Black Board

\begin{tabular}{|l|l|l|l|}
\hline No. of Black Board & $<4$ & $4-6$ & $>6$ \\
\hline No. of Primary School & 45 & 29 & 4 \\
\hline \% of Primary School & 57.69 & 37.17 & 5.12 \\
\hline
\end{tabular}

Source: Primary Council, Krishnagar,Nadia.

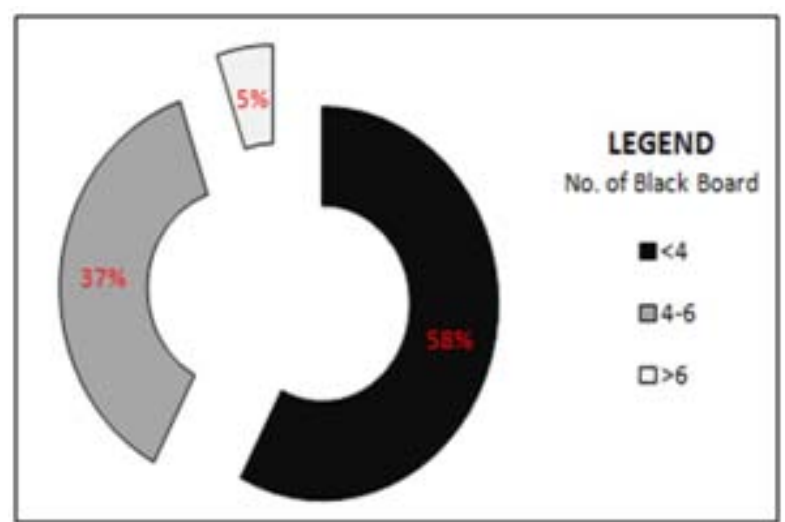

Figure 7: Availability of Black Board in primary school, Krishnagar Municipal Area

\section{Separate Toilet Facility:}

The municipal area reveals that more than half of the surveyed primary schools (53.84\%) have no separate toilet facility. However remaining primary schools have more than $47.43 \%$ of total primary school have separate toilet facility (fig.8). The distribution of toilet facility among the surveyed schools suggests that disparity in distribution of separate toilet facility is not considerable.

Table 7: Separate toilet facility

\begin{tabular}{|c|c|c|}
\hline Separate Toilet Facility & Yes & No \\
\hline No. of Primary School & 37 & 42 \\
\hline \% of Primary School & 47.43 & 53.84 \\
\hline
\end{tabular}

Source: Primary Council, Krishnagar,Nadia.

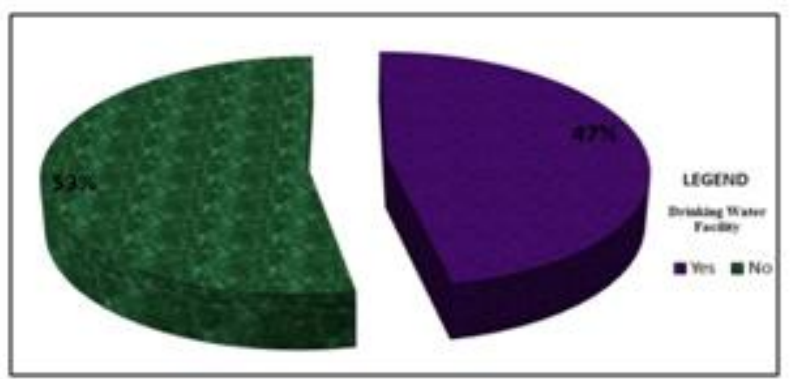

Figure 8: Figure shows Separate toilet facility in Primary school of Study area, 2013

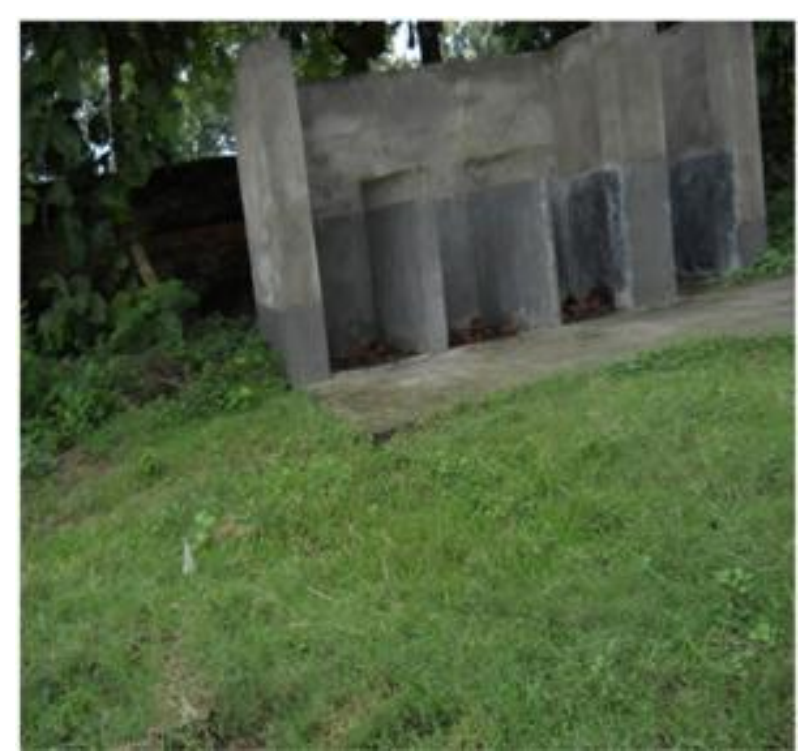

Plate 3: Poor Toilet facility in Sakti mandir harivushan das Primary School, Krishnagar

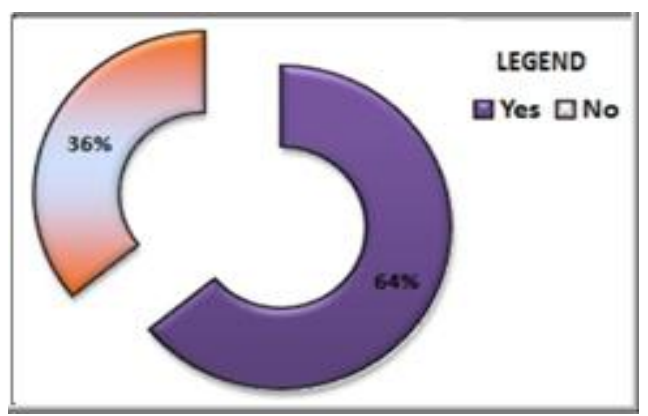

Figure 9: Play ground availability of Primary school in study area

\section{Play ground Availability}

Number of play ground availability is a parameter which provides the basic growth of student's health. So at least one play ground attached in a primary school. It has been found that $64 \%$ of the Primary schools have a play grounds, whereas $36 \%$ of Schools have no play grounds (fig.9).

Table 8: Play ground Availability

\begin{tabular}{|c|c|c|}
\hline Play ground & Yes & No \\
\hline No. of Primary School & 50 & 28 \\
\hline \% of Primary School & 64.10 & 35.89 \\
\hline
\end{tabular}

Source: Primary Council, Krishnagar,Nadia.

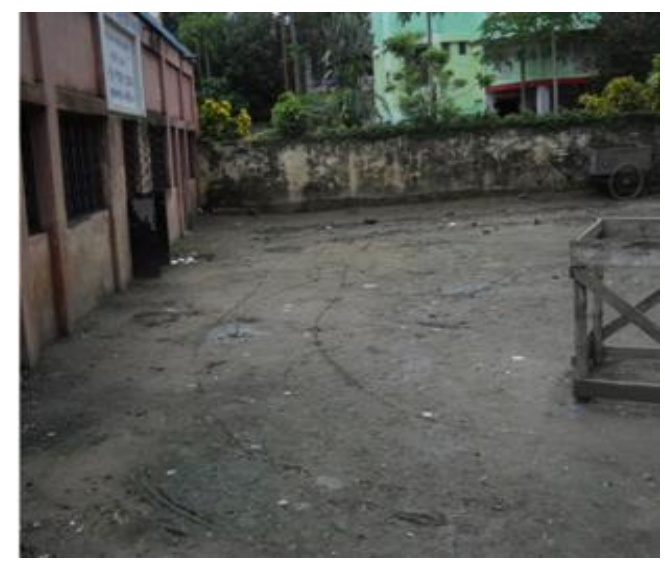

Plate 4: Poor Play ground Structure of Nicer Para Primary School, Krishnagar 


\section{International Journal of Science and Research (IJSR) \\ ISSN (Online): 2319-7064 \\ Index Copernicus Value (2013): 6.14 | Impact Factor (2014): 5.611}

\section{Status of students, teachers' ratio}

Teacher Student ratio is an importent criteria for proper running the Primary Education systemAccording to Right to Education Act, 2009 student teacher ratio is 40:1. Entire krishnagar municipality $11.53 \%$ schools are not follows this act, because students pressure is much high in these schools. Krishnagar municipality is a $1^{\text {st }}$ class city then student pressure is very high these schools are top grad school in Krishnagar. Number of teachers will be increase in these Schools for maintain the Right to Education Act.

Table 9: Students, Teachers Ratio

\begin{tabular}{|c|c|c|}
\hline Student Teacher Ratio & $\begin{array}{c}\text { No. of primary } \\
\text { school }\end{array}$ & $\begin{array}{c}\text { \% of primary } \\
\text { School }\end{array}$ \\
\hline Bellow 40:1 & 69 & 88.46 \\
\hline Above 40:1 & 9 & 11.53 \\
\hline
\end{tabular}

Source: Primary Council, Krishnagar,Nadia.

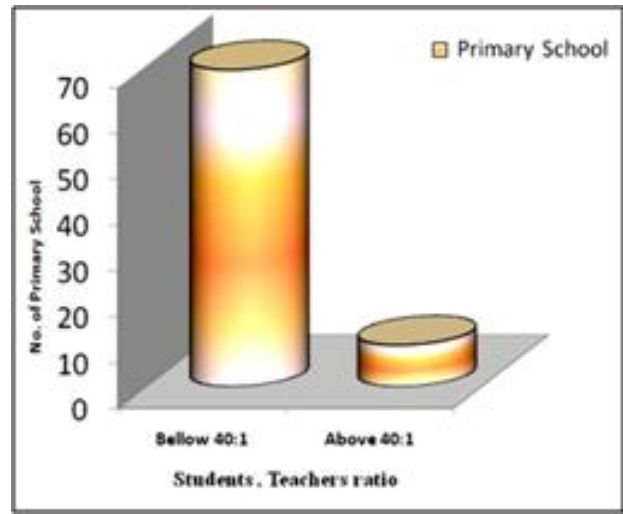

Figure 10: Enrolment of student and teacher ratio of primary school in Krishnagar municipality, 2011-12

\section{Status of basic facilities}

From the given data and weighted index map shows, total score of basic facility available of different primary school in Krishnagar municipality. The minimum basic facilities required for a good education. In the study area of Krishnagar municipality, it was observed during the field survey good basic facilities available in CMS Sent Jons Kouins primary school weighted index score is 25.378. Other side the poor basic facility of primary school is Shaktinagar EGSPFP School the Weighted index score is 3.356. From (Fig 3) In the whole municipality its observed that good condition of primary school situated in ward no. $10,13,14,12,22,23$, because some English medium school and private school situated there. Other side ward no. 7, 9, $15,16,24$, condition of primary school of these wards is so bad because this is slum area and educational awareness is not more batter in this area (fig. 11).

\section{Conclusion}

It may be concluded that,

1) Basic facilities of Primary schools have below standard level in the study area.

2) Technical as well as professional institutes are not present in adequate number of Krishnagar municipality.

3) Primary education program and schemes are not properly implies in the study area.

4) Maximum number of schools have not maintain good student teacher ratio.

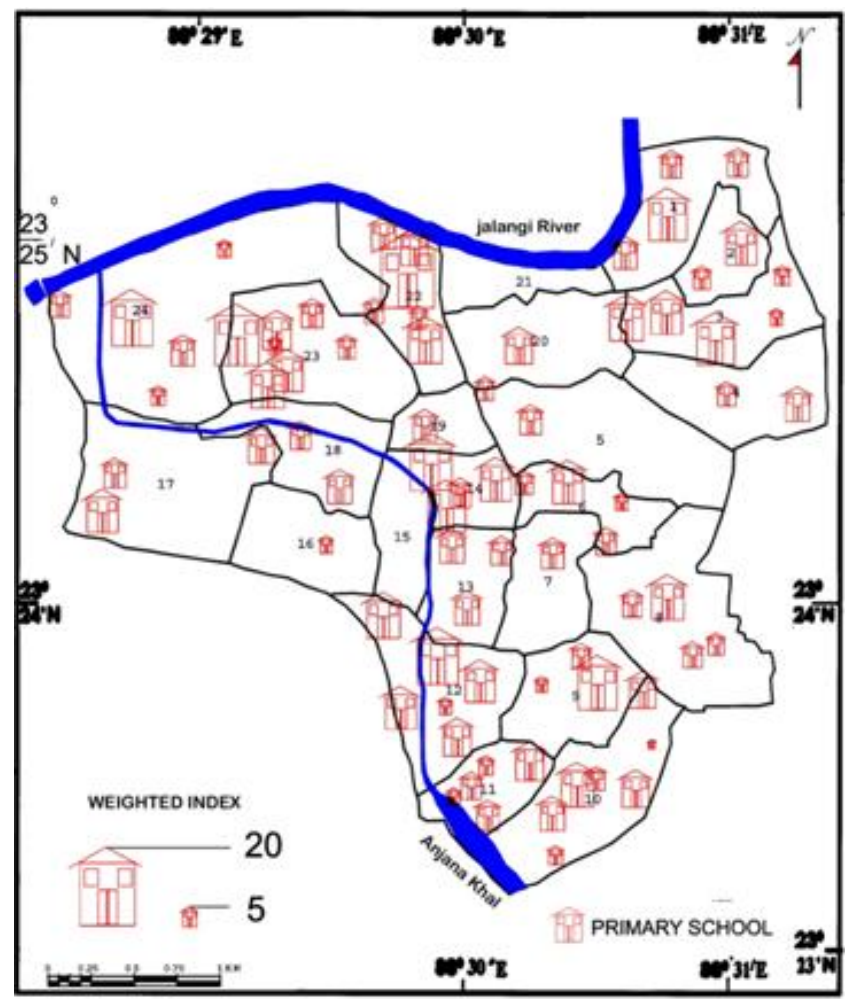

Figure 11: Figure shows Quality of primary school in krishnagar municipality (Weighted Index Method)

Measures Taken to Improve the Primary Schools

1) Apply the all Government initiatives to improve the Primary Education, i.e. SSA, Midday Meal, Kanyashree, Juboshree, Marti Cum Scholarships etc.

2) Improving the basic needs in a primary school (i.e. play ground, books, board etc.) for attracting the students and provide good education.

3) Cluster format school are create, two or more school join each another and create a cluster school.

4) Teaching learning process should be developed and used attracting teaching aids.

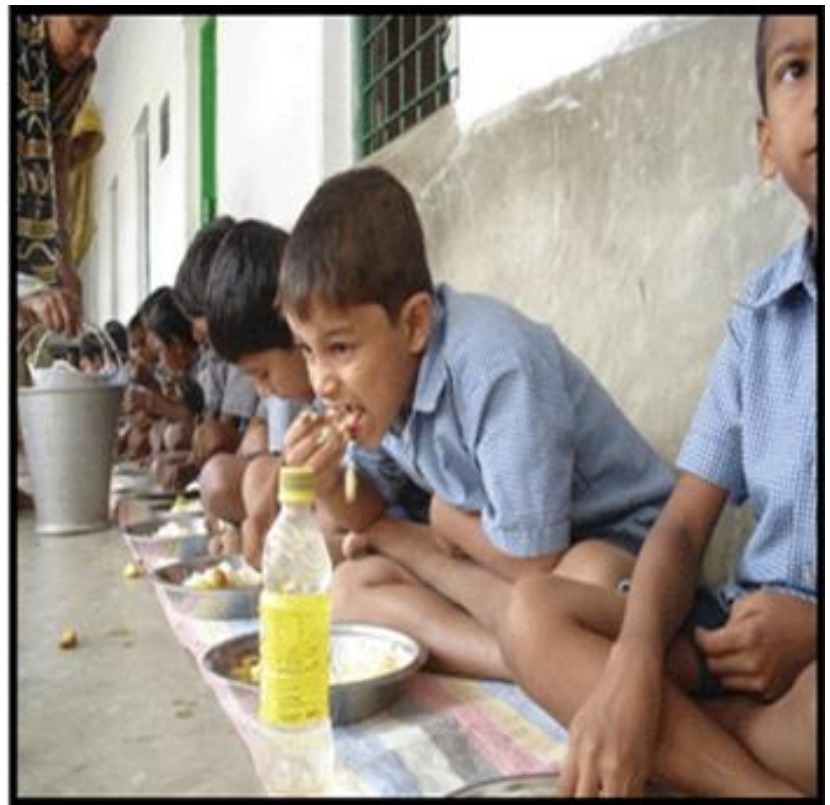

Plate 5: Midday Meal Program conduct in a school, Krishnagar, Nadia 


\section{References}

[1] Ambhore D.K, 2010. Compulsory Primary Education Related To Ruralarea: Problems and Remedies. International referred research journal.

[2] Barnapoprichai Bhavan, Nadia, West Bengal. Census of India 2011. Provisional Population Census, Government of India.

[3] Erten Gokce, 2009. Discrimination In Primary Education In The Slums Of Turkey: Problems About Equity Of Education. International Journal of Human and Social Sciences.

[4] Ghosh Ranjit, 2009-10. Juge Juge Varoter Shikha. published by Ruchira Chakrabarty. In a proceedings seminar entitled "restructuring of school education system in west bengal" organized by the Indian institute of management Calcutta (iimc) on august 2010.

[5] Jain Manish, 2009 IAS(state project director)PBSSM. annual report 2008-09. prepared by: paschim banga sarva shiksha mission.

[6] Kail Kaushik, 2010. Problems and Prospects Of Primary Education In Mathura District: A Geographical Analysis. Journal of geography and regional planning vol. 3(10), pp. 253- 261.

[7] Municipality of Krishnagar , nadia - 741102.

[8] Dr. Sanatan Ghosh, Associated Prof., Krishnath College, Berhampore, Murshidabad(WB)

[9] Uttam Kumar Sardar, Associated Prof., Krishnath College, Berhampore, Murshidabad(WB)

[10]Dr. Indradip Ghosh, Assistant Prof., U.C.T.College, Berhampore, Murshidabad(WB)

\section{Author Profile}

Koushik Barick did M. Sc (Geography). He did B. Ed and qualified SET and NET. He is working as Guest Lecturer, Dukhulal Nibaran Chandra College, Aurangabad, Murshidabad (W.B) 